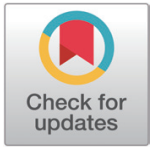

Received: Oct 7, 2021

Revised: Nov 17, 2021

Accepted: Jan 8, 2022

*Corresponding author Humberto González-Ríos Centro de Investigación en Alimentación y Desarrollo, A.C. (CIAD, A.C.), Sonora 83304, Mexico. Tel: +52-662-289-2400

E-mail: hugory@ciad.mx

Copyright $\odot 2022$ Korean Society of Animal Sciences and Technology.

This is an Open Access article distributed under the terms of the Creative Commons Attribution Non-Commercial License (http:// creativecommons.org/licenses/by$\mathrm{nc} / 4.0 /$ ) which permits unrestricted non-commercial use, distribution, and reproduction in any medium, provided the original work is properly cited.

ORCID

Edgar Fernando Peña-Torres https://orcid.org/0000-0002-0867-8575 Candelario Castillo-Salas

https://orcid.org/0000-0003-0206-0675 Ismael Jiménez-Estrada

https://orcid.org/0000-0003-2751-3554

\title{
Growth performance, carcass traits, muscle fiber characteristics and skeletal muscle mRNA abundance in hair lambs supplemented with ferulic acid
}

Edgar Fernando Peña-Torres ${ }^{1,2}$, Candelario Castillo-Salas ${ }^{3}$, Ismael Jiménez-Estrada ${ }^{4}$, Adriana Muhlia-Almazán ${ }^{2}$, Etna Aida Peña-Ramos ${ }^{2}$, Araceli Pinelli-Saavedra ${ }^{2}$, Leonel Avendaño-Reyes ${ }^{5}$, Cindy Hinojosa-Rodríguez ${ }^{4}$, Martin Valenzuela-Melendres ${ }^{2}$, Ulises Macias-Cruz ${ }^{5}$ and Humberto González-Ríos ${ }^{2 *}$

${ }^{1}$ División de Ciencias de la Salud, Universidad de Quintana Roo, Quintana Roo 77039, Mexico

${ }^{2}$ Centro de Investigación en Alimentación y Desarrollo, A.C. (CIAD, A.C.), Sonora 83304, Mexico

${ }^{3}$ Departamento de Ciencias Agronómicas y Veterinarias, Instituto Tecnológico de Sonora, Sonora 85000 , Mexico

${ }^{4}$ Departamento de Fisiología, Biofísica y Neurociencias, Centro de Investigación y Estudios Avanzados del IPN, San Pedro Zacatenco 07000, Mexico

${ }^{5}$ Instituto de Ciencias Agrícolas, Universidad Autónoma de Baja California, Baja California 21705, Mexico

Abstract

Ferulic acid (FA) is a phytochemical with various bioactive properties. It has recently been proposed that due to its phytogenic action it can be used as an alternative growth promoter additive to synthetic compounds. The objective of the present study was to evaluate the growth performance, carcass traits, fiber characterization and skeletal muscle gene expression on hair-lambs supplemented with two doses of FA. Thirty-two male lambs $(n=8$ per treatment) were individually housed during a $32 \mathrm{~d}$ feeding trial to evaluate the effect of $\mathrm{FA}$ (300 and $600 \mathrm{mg} \mathrm{d}^{-1}$ ) or zilpaterol hydrochloride ( $\mathrm{ZH} ; 6 \mathrm{mg} \mathrm{d}^{-1}$ ) on growth performance, and then slaughtered to evaluate the effects on carcass traits, and muscle fibers morphometry from Longissimus thoracis (LT) and mRNA abundance of $\beta_{2}$-adrenergic receptor $\left(\beta_{2}-\mathrm{AR}\right), \mathrm{MHC}-\mathrm{I}$, MHC-IIX and IGF-I genes. FA increased final weight and average daily gain with respect to non-supplemented animals $(p<0.05)$. The ZH supplementation increased LT muscle area, with respect to FA doses and control $(p<0.05)$. Cross-sectional area (CSA) of oxidative fibers was larger with FA doses and $\mathrm{ZH}(p<0.05)$. Feeding $\mathrm{ZH}$ increased mRNA abundance for $\beta_{2}$-AR compared to FA and control $(p<0.05)$, and expression of MHC-I was affected by FA doses and ZH $(p<0.05)$. Overall, FA supplementation of male hair lambs enhanced productive variables due to skeletal muscle hypertrophy caused by MHC-I up-regulation. Results suggest that FA has the potential like a growth promoter in lambs.

Keywords: Ferulic acid, Feedlot lambs, Muscle morphometry, Real-time polymerase chain reaction 
Adriana Muhlia-Almazán

https://orcid.org/0000-0001-9398-7980

Etna Aida Peña-Ramos

https://orcid.org/0000-0001-7990-2514

Araceli Pinelli-Saavedra

https://orcid.org/0000-0003-1487-5767

Leonel Avendaño-Reyes

https://orcid.org/0000-0001-5477-5707

Cindy Hinojosa-Rodríguez

https://orcid.org/0000-0002-9493-9152

Martin Valenzuela-Melendres

https://orcid.org/0000-0002-7347-9599

Ulises Macias-Cruz

https://orcid.org/0000-0002-6947-2247

Humberto González-Ríos

https://orcid.org/0000-0002-7463-778X

Competing interests

No potential conflict of interest relevant to

this article was reported.

Funding sources

Not applicable.

\section{Acknowledgements}

The authors are grateful to Sandra $R$. Araujo Bernal, for her support in the gene expression analysis. CONACYT's (Consejo Nacional de Ciencia y Tecnología, Mexico) financial support from the first author's postgraduate scholarship is similarly appreciated.

Availability of data and material Upon reasonable request, the datasets of this study can be available from the corresponding author.

\section{Authors' contributions}

Conceptualization: González-Ríos H.

Data curation: Peña-Torres EF, JiménezEstrada I, Peña-Ramos EA, ValenzuelaMelendres M, Macias-Cruz U.

Formal analysis: Peña-Torres EF, MuhliaAlmazán A, Hinojosa-Rodríguez C.

Investigation: Peña-Torres EF, Castillo-Salas C, Pinelli-Saavedra A, Avendaño-Reyes L, González-Rios $\mathrm{H}$.

Methodology: Peña-Torres EF, JimenezEstrada I, Muhlia-Almazán A, PeñaRamos EA, Pinelli-Saavedra A Avendaño-Reyes L, Hinojosa-Rodríguez C, González-Rios H.

Writing - original draft: Peña-Torres EF, PeñaRamos EA, Macias-Cruz U.

Writing - review \& editing: Peña-Torres EF, Castillo-Salas C, Jiménez-Estrada I, Muhlia-Almazán A, Peña-Ramos EA, Pinelli-Saavedra A, Avendaño-Reyes L, Hinojosa-Rodríguez C, ValenzuelaMelendres M, Macias-Cruz U, GonzálezRios $\mathrm{H}$.

Ethics approval and consent to participate All protocols and experimental procedures were approved and supervised by the Research Ethics Committee of Centro de Investigación en Alimentación y Desarrollo (CIAD) (ID: CE/034/2018).

\section{INTRODUCTION}

Recently, the use of phytochemicals in meat-producing animals has gained importance due to their bioactive properties, including antioxidants, antimicrobials, immunomodulators, or growth promoters [1]. Ferulic acid (FA, 4-hydroxy-3-methoxycinnamic acid) is a phytochemical commonly linked to polysaccharides such as arabinoxylans, xyloglucans pectin, and cell walls, and is present in a wide range of natural sources, including fruits, vegetables, cereals, and grains [2,3].

Recent studies with FA supplemented in meat-producing animals have shown a reduction in fat thickness and improved carcass yields and meat quality in pigs, bovines, and lambs; however, the mode of action remains unclear, and several potential mechanisms have been suggested like mimicking $\beta$-AA action by increase of muscle protein synthesis and reduction of body fat, hormonal activation or antioxidant like preventing endogenous protein oxidation [47]. In contrast, $\beta$-adrenergic agonists $(\beta-\mathrm{AA})$ are synthetic growth promoters, analogs of catecholamines, and are commonly used in animal production with significant results in growth performance and carcass traits [8]. The biological mechanism is through binding to the $\beta$-adrenergic receptor ( $\beta$-AR) situated on the cell surface of skeletal muscle and adipose tissue [9]. These compounds generate an overexpression of $\beta 1-\mathrm{AR}, \beta 2-\mathrm{AR}$, and myosin heavy chain (MHC) and hormonal factors such as insulin growth factor (IGF), changes in protein synthesis rates, and larger muscle fibers [10,11].

$\beta$-AA compounds such as zilpaterol hydrochloride $(\mathrm{ZH})$ have adverse effects on meat quality and are banned from the European Union or Asian countries [12,13]. Thus, the use of natural compounds such as FA can be a favorable alternative to synthetic growth promoters. Currently, there are no data on the histological and gene expression of lambs supplemented with FA. Supplementation of commercial lambs with FA (300 mg or $600 \mathrm{mg} \mathrm{d}^{-1}$ ) might improve the productive parameters and protein synthesis by $\beta$-AR binding and evidenced by $\mathrm{MHC}$ isoforms expression. The objective of the present study was to evaluate the growth performance, carcass traits, fiber characterization, and skeletal muscle gene expression in hair lambs supplemented with two doses of FA.

\section{MATERIALS AND METHODS}

Growth performance and carcass evaluations were conducted at an ovine commercial farm located in the northwestern region of Mexico $\left(100^{\circ} \mathrm{N}, 27^{\circ} \mathrm{W}\right)$ during spring. Morphometry of muscle fibers was performed at the Centro de Investigación y de Estudios Avanzados, located in Ciudad de Mexico, Mexico. The gene expression evaluation was conducted at the Centro de Investigación en Alimentación y Desarrollo (CIAD), located in Hermosillo, Sonora, Mexico. All handling procedures involving lambs were performed within the guidelines of approved official techniques for animal care in Mexico (NOM-051-ZOO, 1995: Humanitarian care of animals during mobilization; NOM-033-SAG/ZOO, 2014: Slaughter methods for domestic and wild animals). All protocols and experimental procedures were approved and supervised by the Research Ethics Committee of CIAD (ID: CE/034/2018).

\section{Animals and treatments}

The study was performed with 32 male lambs (Dorper $\times$ Pelibuey) with an initial weight of $24 \pm$ $3 \mathrm{~kg}$ at 4 months of age. All lambs were allocated to individual pens equipped with feeders and waterers. The lambs were adapted to the pens and a basal diet for two weeks prior to the start of the experimental period. The basal diet was formulated according to the recommendations of the National Research Council (Table 1). Prior to the experimental trial, lambs received an injection 
Table 1. Basal diet composition (dry matter \%) of hairbreed lambs

\begin{tabular}{|c|c|}
\hline Ingredients & Percentage \\
\hline Ground corn grain & 55.5 \\
\hline Alfalfa hay & 22.5 \\
\hline Wheat straw & 2.1 \\
\hline Cotton seed meal & 13.16 \\
\hline Soybean meal & 4.0 \\
\hline Cane molasses & 1.23 \\
\hline Calcium carbonate & 0.46 \\
\hline Salt & 0.46 \\
\hline Minerals ${ }^{1)}$ & 0.46 \\
\hline Dry matter (\%) & 89.64 \\
\hline $\mathrm{ME}^{2)}\left(\mathrm{Mcal} \mathrm{kg}^{-1}\right)$ & 2.88 \\
\hline Crude protein & 15.56 \\
\hline
\end{tabular}

${ }^{1)}$ Trace minerals (Fe, 4,000 mg kg ${ }^{-1} ; 92 \mathrm{Mn}, 4,800 \mathrm{mg} \mathrm{kg}^{-1} ; \mathrm{Zn}, 5,460 \mathrm{mg} \mathrm{kg}^{-1} ; \mathrm{Cu}, 1,000 \mathrm{mg} \mathrm{kg}^{-1} ; \mathrm{I}, 140 \mathrm{mg} \mathrm{kg}^{-1} ; \mathrm{Co}, 16.6 \mathrm{mg}$ $\mathrm{kg}^{-1} ;$ Se, $\left.16.4 \mathrm{mg} \mathrm{kg}^{-1}\right)$.

${ }^{2} \mathrm{ME}$, metabolizable energy based on ME values for each ingredient.

of vitamins A, D, and E (Vigantol, Bayer, Mexico City, Mexico; $1 \mathrm{~mL} / \mathrm{animal})$ and were treated for internal and external parasites (Ivermectin, Sanfer Laboratory, Mexico City, Mexico; $0.5 \mathrm{~mL} /$ animal). At the end of the adaptation period, the animals were individually weighed and randomly assigned to one of the following treatments ( $\mathrm{n}=8$ per treatment): 1$)$ a basal diet without additives (control); 2) $300 \mathrm{mg} \mathrm{d}^{-1}$ of FA (FA300; Laboratorios Minkab SA, de CV, Guadalajara, Jalisco, Mexico); 3) $600 \mathrm{mg} \mathrm{d}^{-1}$ of FA (FA600); and 4) $6 \mathrm{mg} \mathrm{d}^{-1}$ of ZH (Grofactor ${ }^{\circledR}$, Laboratorio Virbac, Mexico). The feeding period was 32 days, and $\mathrm{ZH}$ was withdrawn $72 \mathrm{~h}$ prior to animal slaughter.

To ensure the complete intake of additives, initially, each dose of FA300, FA600 or ZH were weighed and immediately mixed with $50 \mathrm{~g}$ of the basal diet and given to each individual lamb, ensuring the total consumption of the additive with the $50 \mathrm{~g}$ of feed, later the rest of the diet without additive was provided in the feeders. In the control group, $50 \mathrm{~g}$ of diet without additives was also given. Fresh drinking water was available during the experiment, and feed was provided at $0800 \mathrm{~h}$ and $1600 \mathrm{~h}$.

Climatic conditions at the experimental site ranged from $17^{\circ} \mathrm{C}$ to $37^{\circ} \mathrm{C}$, and the average relative humidity (RH) was $30.5 \%$. The temperature-humidity index (THI) was calculated according to the equation described by Hahn [14] with the temperature average (Te) and RH: THI $=0.81 \times$ $\mathrm{Te}+\mathrm{RH} / 100(\mathrm{Te}-14.40)+46.40$. Based on the THI values, climatological conditions were considered thermoneutral $\left(\mathrm{THI} \leq 74, \mathrm{Te}=20.68 \pm 2.17^{\circ} \mathrm{C}, \mathrm{RH}=42 \pm 9.58 \%, \mathrm{THI}=65.72 \pm 2.55\right.$ units). The health status of the animals was monitored throughout the experiments.

\section{Growth performance}

The lambs were weighed individually to record their initial and final body weights. The average daily gain (ADG) was estimated as the difference between the initial and final weights divided by the feeding days. The feed provided and feed refused in each pen were recorded daily to calculate feed intake and expressed as dry matter. Feed conversion per pen/treatment based on the average feed intake and ADG was calculated.

\section{Carcass traits and muscle sample collecting}

All slaughter procedures complied with the current regulations (NOM-033-SAG/ZOO, 2014: 
Slaughter methods for domestic and wild animals). The lambs were fasted from feed and water for at least $12 \mathrm{~h}$ before slaughter. Subsequently, the lambs were transported to the abattoir located next to the commercial farm and slaughtered by exsanguination. The lambs were skinned and eviscerated, and the hot carcass weight (HCW), dressing percentage, Longissimus thoracis (LT) area in $\mathrm{cm}^{2}$, and fat thickness $(\mathrm{mm})$ at the 12 th rib from the left side of the carcass were recorded. Muscle $\mathrm{pH}$ was measured at $45 \mathrm{~min}$ and $24 \mathrm{~h}$ postmortem at the 12th intercostal space using a portable $\mathrm{pH}$ meter (HANNA HI 99163, Mettler Toledo Process Analytical. Wilmington, MA, USA).

LT muscle samples were collected at 10 min postmortem (transversal cuts at 10th intercostal space from the right side of the carcass) and immediately cryopreserved with cooled isopentane (SigmaAldrich, St. Louis, MO, USA) and liquid nitrogen for histoenzymatic and gene expression analysis and shipped to CIAD.

\section{Fiber characterization of Longissimus thoracis muscle by histoenzymatic stains}

Transverse sections of cryopreserved muscle were cut to $10 \mu \mathrm{m}$ thickness using a cryostat microtome at $-20^{\circ} \mathrm{C}$ (CM-1100, Leica Microsystems, Nussloch, Germany) and mounted on glass slides for subsequent analysis of nicotine-amide adenine dinucleotide tetrazolium reductase (NADH-TR) and alkaline ATPase staining. Briefly, to determine the characteristics of oxidative or glycolytic fibers, muscle sections were stained using the NADH-TR technique [15]. Then, glass slides with muscle sections were incubated in Coplin staining jars for $1 \mathrm{~h}$ at $37^{\circ} \mathrm{C}$ in nitro-blue tetrazolium (NBT)-NADH solution 1:1 v/v (1.2 mM NBT [Sigma-Aldrich] diluted in $50 \mathrm{mM}$ Tris buffer [BioRad, Irvine, CA, USA], pH 7.6; 2.25 mM nicotinamide adenine dinucleotide [NADH, SigmaAldrich] diluted in $50 \mathrm{mM}$ Tris buffer [BioRad]]. The glass slides were then washed three times with deionized water. Excess NBT-NADH solution was removed with acetone washes (30\%, 60\%, and $90 \%)$.

The alkaline ATPase technique ( $\mathrm{pH}$ 9.4) was performed according to the method described by Guth and Samaha [16]. Muscle sections in glass slides were submerged in Coplin staining jars with pre-incubation solution (Tris base $10 \mathrm{mM}$ [BioRad] and $18 \mathrm{mM} \mathrm{CaCl}_{2}$ [J.T. Baker, Mexico City, Mexico], $\mathrm{pH}$ 10.3) for $15 \mathrm{~min}$. Subsequently, the glass slides were washed three times with deionized water and incubated for $1 \mathrm{~h}$ at $37^{\circ} \mathrm{C}$ in a working solution of Tris buffer with adenosine 5'-triphosphate (Sigma-Aldrich) at $\mathrm{pH}$ 9.4. Muscle sections were washed with $200 \mathrm{mM} \mathrm{CaCl}$ for 3 min, followed by 2\% (w/v) $\mathrm{CoCl}_{2}$ (Sigma-Aldrich, Gillingham, UK) for 3 min and 10\% (v/v) ammonium sulfide (Sigma-Aldrich) for $3 \mathrm{~min}$, and then washing with deionized water.

Muscle fibers of both techniques were measured using a light optical microscope (Nikon Eclipse E600, Nikon, Tokyo, Japan) adapted to an Olympus C-5060 digital camera (Olympus, Tokyo, Japan) at 10x amplification. Muscle fiber typing using the NADH-TR technique was classified into oxidative and glycolytic, and fibers were identified by the alkaline ATPase technique as slow (type I), intermediate (IIA), and fast (type IIB) (Fig. 1). The total number of each fiber type for each stains, was determined using the Image J program and expressed as percentage of the total number of fibers scored, and the cross-sectional area $\left(\mathrm{CSA}, \mu \mathrm{m}^{2}\right)$ was measured in sample from the 10th intercostal space of the LT muscle in 200 randomly selected fibers of each fiber type stained with NADH-TR and alkaline ATPase according to described by López-García et al. [17]. Additionally, muscle fiber density was determined by counting the number of each fiber type in $50000 \mu^{2}$ of muscle sections according to the method described by Valenzuela-Grijalva et al. [18]. All data were determined and recorded using Image J version 1.45s software (NIH, Bethesda, MD, USA).

\section{Gene expression by real-time quantitative polymerase chain reaction}

The total RNA of samples from the LT muscle was obtained according to the methodology 


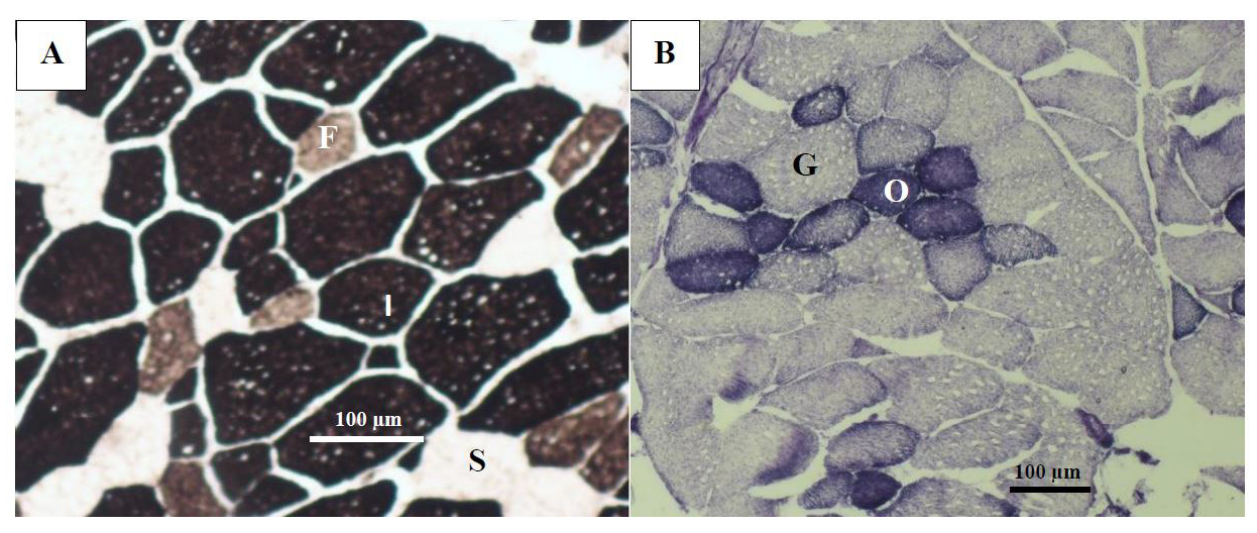

Fig. 1. Fiber type was categorized according to the following criteria. Alkaline ATPase technique (A), light fibers were identified as slow (S, type I), dark fibers as intermediate (I, type Ilb), and brown fibers as fast (F); for $\mathrm{NADH}-\mathrm{TR}$ technique $(\mathrm{B})$, light fibers were identified as glycolytic $(\mathrm{G})$ and dark fibers as oxidative $(\mathrm{O})$. Bar $=100$ $\mu \mathrm{m}$. NADH-TR, nicotine-amide adenine dinucleotide tetrazolium reductase.

described by Baxa et al. [19]. A sample of muscle (200 mg) was added into $2 \mathrm{~mL}$ tubes (Lysing Matrix A tubes, MP Biomedicals, Solon, OH, USA) with $1 \mathrm{~mL}$ of Trizol reagent (Life Technologies, Carlsbad CA, USA) and homogenized for 60 s (FastPrep-24-5G, MP Biomedicals), incubated for $2-3 \mathrm{~min}$ at $2^{\circ} \mathrm{C}$, and then centrifuged for $10 \mathrm{~min}$ at $12,000 \times \mathrm{g}$ at $4^{\circ} \mathrm{C}$. The upper aqueous phase was transferred to a new microtube with $0.3 \mathrm{~mL}$ of chloroform, incubated for $3 \mathrm{~min}$ at $2^{\circ} \mathrm{C}$, and centrifuged for $15 \mathrm{~min}$ at $12,000 \times \mathrm{g}$ at $4^{\circ} \mathrm{C}$. The upper aqueous phase was recovered and transferred into a new microtube with $0.3 \mathrm{~mL}$ of chloroform and centrifuged for $15 \mathrm{~min}$ at $12,000 \times \mathrm{g}$ at $4^{\circ} \mathrm{C}$. Next, the upper aqueous phase was recovered, Trizol $(0.5 \mathrm{~mL})$ was added, and the tube was incubated for $5 \mathrm{~min}$ at $2{ }^{\circ} \mathrm{C}$ and later was added $0.3 \mathrm{~mL}$ of chloroform and mixed for $15 \mathrm{~s}$. The sample was incubated for $3 \mathrm{~min}$ at $4^{\circ} \mathrm{C}$ and centrifuged for $15 \mathrm{~min}$ at $12,000 \times \mathrm{g}$ at $4^{\circ} \mathrm{C}$. The aqueous phase was collected, transferred into a new microtube with isopropanol $(0.5 \mathrm{~mL})$, and incubated for $10 \mathrm{~min}$ at $4^{\circ} \mathrm{C}$. Subsequently, the sample was centrifuged for $15 \mathrm{~min}$ at $12,000 \times \mathrm{g}$ at $4^{\circ} \mathrm{C}$, the isopropanol was removed, and the RNA pellet was suspended in $1 \mathrm{~mL}$ of $75 \%$ ethanol, centrifuged for $5 \mathrm{~min}$ at $7,500 \times \mathrm{g}$ at $4^{\circ} \mathrm{C}$. The supernatant was discarded, and the RNA pellet was suspended in $30 \mu \mathrm{L}$ of diethyl pyrocarbonate (DEPC) water and stored at $-20^{\circ} \mathrm{C}$ for subsequent analysis.

The RNA concentration was determined by measuring the absorbance at 260 and $280 \mathrm{~nm}$ using a NanoDrop spectrophotometer (ND-1000 spectrophotometer, NanoDrop, Wilmington, DE, USA). A A260/A280 ratio of $~ 2.0$ was used to assess RNA purity. The integrity of total RNA was evaluated by electrophoresis (65V, $40 \mathrm{~min}$ ) in a $2 \%$ agarose gel (agarose; Sigma-Aldrich). The RNA was treated with a DNAse-I recombinant-RNAase-free kit (Sigma-Aldrich) to remove genomic DNA from the pellet.

The gene expression of $\beta_{2}$-AR, MHC-I, MHC-IIX, and IGF-I in muscle tissue were determined using Real-time (RT)- quantitative polymerase chain reaction (qPCR). Hence, ribosomal protein s9 (RPS9) gene was used for normalization [20]. Retro-transcription to cDNA and RT-PCR reaction were performed in one step using 2X One-Step Brillant II QRT-PCR Low Rox Master Mix reagent and reverse transcriptase enzyme (Agilent Technologies, Santa Clara, CA, USA), $1 \mu \mathrm{L}$ of TaqMan probe and $0.8 \mu \mathrm{L}$ of RNA template (400 $\mathrm{ng}$ of RNA). The lamb-specific $\beta_{2}$-AR, MHC-I, MHC-IIX, IGF-I, and RPS9 forward, reverse, and TaqMan detection probes were designed using published GenBank sequences (Table 2). All sequences were synthetized using 
Table 2. Primers and TaqMan probes of $\beta_{2}$-adrenergic receptor, myosin heavy chain I and IIX (MHC) and insulin growth factor-I (IGF-I)

\begin{tabular}{|c|c|}
\hline Item & Sequence $\left(5^{\prime}\right.$ to $\left.3^{\prime}\right)$ \\
\hline \multicolumn{2}{|c|}{$\beta_{2}$-Adrenergic receptor (accession No. NM_001130154.1) } \\
\hline Forward & 5'-TGCAGACGGTCACCAACTAC-3' \\
\hline Reverse & 3'-ACGTCAGTCAAGTGGAGCAG-5' \\
\hline Taqman probe & 5'-FAM-CCGGGCCAGCCACAAGGAAG-IABLKFQ-3' \\
\hline \multicolumn{2}{|l|}{ MHC-I (accession No. AB058898.1) } \\
\hline Forward & 5'-GACGTCTTTGTGCCTGATGA-3' \\
\hline Reverse & 3'-ACAGAGCATGGCAAGACAG-5' \\
\hline Taqman probe & 5'-FAM-AAGAGGAGTTCGTCAAGGCCACAA-IABLKFQ-3' \\
\hline \multicolumn{2}{|l|}{ MHC-IIX (accession No. AB058897.1) } \\
\hline Forward & 5'-GATTGGGCTGCCATCAATAAC-3' \\
\hline Reverse & 3'-TTTCAGACTTTCGGAGGTAAGG-5' \\
\hline Taqman probe & 5'-FAM-TTCCTGGTCTGAACTCATGGCTGC-IABLKFQ-3 \\
\hline \multicolumn{2}{|l|}{ IGF-I (accession No. NM_001009774.3) } \\
\hline Forward & 5'-TCCCATCTCCCTGGATTTCT-3' \\
\hline Reverse & 3'-AATCAGCAGTCTTCCAACCC-5' \\
\hline Taqman probe & 5'-FAM-CAGACTTTGCACTTCAGAAGCAATGGG-IABLKFQ-3' \\
\hline \multicolumn{2}{|l|}{ RPS9 (accession No. XM_015100112.1) } \\
\hline Forward & 5'-CTGACGCTGGATGAGAAAGA-3' \\
\hline Reverse & 3'-CTTCAGGCCCAGGATGTAAT-5' \\
\hline Taqman probe & 5'-FAM-TGCTGGACGAGGGCAAGATGAAG-IABLKFQ-3' \\
\hline
\end{tabular}

RPS9, ribosomal protein s9.

Single Tube TaqMan Gene Expression assays (Applied Biosystems Integrated DNA Technologies).

Real-time quantitative analysis was performed using the StepOne ${ }^{\mathrm{TM}}$ RT-PCR system (Applied Biosystems, Foster City, CA, USA) following the conditions recommended by the manufacturer's protocol: 1 cycle of $30 \mathrm{~min}$ at $50^{\circ} \mathrm{C}, 1$ cycle of $10 \mathrm{~min}$ at $95^{\circ} \mathrm{C}, 40$ cycles of $15 \mathrm{~s}$ at $95^{\circ} \mathrm{C}$, and 40 cycles of $1 \mathrm{~min}$ at $60^{\circ} \mathrm{C}$. PCRs were evaluated in triplicate, non-template controls were included, and the results were normalized to RPS9 expression levels. Relative gene expression was calculated using the $2^{-\Delta \Delta C t}$ method, and data were expressed as relative units [21].

\section{Statistical analysis}

Data on growth performance, carcass characteristics, histoenzymatic parameters, and gene expression were analyzed with a general linear model-analysis of variance for a randomized complete design. The model included treatments as a fixed effect, and the initial body weight of animals as a covariate for growth performance and carcass trait variables. Mean comparisons were performed using the Tukey-Kramer test. Statistical significance was considered at $p<0.05$. All data were processed using the statistical package NCSS version 11.

\section{RESULTS}

\section{Growth performance and carcass traits}

The results of the feedlot performance are presented in Table 3. The final body weight was affected by treatments $(p<0.05)$, where FA doses were higher than the control, indicating an additive effect of FA. The ADG of animals fed with FA was higher than the control $(p<0.05)$, and the ADG of animals fed with FA or $\mathrm{ZH}$ was similar $(p>0.05)$. The feed intake was not affected by treatments 
Table 3. Growth performance and carcass traits of hair lambs supplemented with ferulic acid or zilpaterol hydrochloride

\begin{tabular}{|c|c|c|c|c|c|c|}
\hline \multirow[t]{2}{*}{ Items } & \multicolumn{4}{|c|}{ Treatments $^{1)}$} & \multirow{2}{*}{ SEM } & \multirow{2}{*}{$p$-value } \\
\hline & Control & FA300 & FA600 & $\mathrm{ZH}$ & & \\
\hline Initial body weight (kg) & 23.55 & 24.80 & 23.77 & 23.98 & 1.74 & 0.751 \\
\hline Final body weight (kg) & $30.27^{\mathrm{a}}$ & $32.56^{b}$ & $32.54^{b}$ & $31.94^{\mathrm{ab}}$ & 0.56 & 0.049 \\
\hline Average daily gain $(\mathrm{kg})$ & $0.195^{\mathrm{a}}$ & $0.265^{b}$ & $0.265^{\mathrm{b}}$ & $0.257^{\mathrm{ab}}$ & 0.01 & 0.032 \\
\hline Feed intake $\left(\mathrm{kg} \mathrm{DM} \mathrm{d}^{-1}\right)$ & 0.98 & 1.07 & 1.13 & 1.13 & 0.06 & 0.265 \\
\hline Feed conversion (kg DM) & 5.05 & 4.07 & 4.27 & 4.38 & 0.41 & 0.382 \\
\hline Hot carcass weight (kg) & 15.02 & 15.53 & 15.45 & 15.31 & 0.34 & 0.711 \\
\hline Hot carcass dressing (\%) & 48.24 & 48.01 & 47.61 & 48.54 & 0.72 & 0.839 \\
\hline LT area $\left(\mathrm{cm}^{2}\right)$ & $14.40^{\mathrm{a}}$ & $14.40^{\mathrm{a}}$ & $13.68^{\mathrm{a}}$ & $16.18^{b}$ & 0.42 & 0.031 \\
\hline Fat thickness (mm) & 1.80 & 2.78 & 2.03 & 2.85 & 0.44 & 0.342 \\
\hline $\mathrm{pH} 45 \mathrm{~min}$ & 6.48 & 6.44 & 6.38 & 6.39 & 0.06 & 0.272 \\
\hline $\mathrm{pH} 24 \mathrm{~h}$ & 5.59 & 5.58 & 5.71 & 5.59 & 0.03 & 0.444 \\
\hline
\end{tabular}

Temperature-humidity index ( $\mathrm{THI})$ : $\mathrm{THI} \leq 74, \mathrm{Te}=20.68 \pm 2.17^{\circ} \mathrm{C}, \mathrm{RH}=42 \pm 9.58 \%, \mathrm{THI}=65.72 \pm 2.55$ units.

${ }^{1)}$ Basal diet without additive (Control); basal diet plus $300 \mathrm{mg}$ of FA d $^{-1}$ (FA300); basal diet plus $600 \mathrm{mg}$ of FA d ${ }^{-1}$ (FA600); basal diet plus zilpaterol hydrochloride at $6 \mathrm{mg} \mathrm{d}^{-1}$ (ZH). $\mathrm{n}=8$.

a,b Means with different superscripts in same row, indicate significant differences $(p<0.05)$.

FA, ferulic acid; ZH, zilpaterol hydrochloride; DM, dry matter; LT, Longissimus thoracis; RH, relative humidity.

$(p>0.05)$, with values ranging between 1.10 and $1.26 \mathrm{~kg} \mathrm{~d}^{-1}$. Similarly, feed conversion was similar among treatments $(p>0.05)$.

The carcass characteristics of lambs supplemented with FA and $\mathrm{ZH}$ are presented in Table 3 . The HCW and dressing percentage were not modified by the treatments $(p>0.05)$. Animals supplemented with $\mathrm{ZH}$ had higher LT area than animals in the other treatments $(p<0.05)$. The carcass fat thickness was not modified by treatments $(p>0.05)$, with values that ranged between 1.80 and $2.85 \mathrm{~mm}$ for all treatments. The $\mathrm{pH}$ at $45 \mathrm{~min}$ and $24 \mathrm{~h}$ postmortem did not change among treatments $(p>0.05)$, with the $\mathrm{pH}$ range at $45 \mathrm{~min}$ from 6.38 to 6.48 , and at $24 \mathrm{~h}$ from 5.59 to 5.71 .

Fiber type characterization of Longissimus thoracis muscle using histoenzymatic staining

Transversal sections of muscle stained with NADH-TR differentiated the type of fibers according to their metabolism (oxidative and glycolytic), and ATPase staining identified fibers as slow or type I, intermediate or type IIA, and fast or type IIB fibers according to their contractile characteristics.

Fiber percentage and morphometry of muscle fiber using nicotine-amide adenine dinucleotide tetrazolium reductase staining

The treatments did not affect the percentages of oxidative and glycolytic fibers $(p>0.05)$, with percentages between $41.10 \%-42.64 \%$ and $57.35 \%-58.89 \%$, respectively (Table 4). The CSA of oxidative fibers was larger in the FA and $\mathrm{ZH}$ treatments than in the control $(p<0.05)$; both FA and $\mathrm{ZH}$ increased the CSA between 800 and $1,000 \mu \mathrm{m}^{2}$ compared to the control. Therefore, CSA in oxidative fibers in the FA treatments was similar to that in the $\mathrm{ZH}$ treatment $(p>0.05)$.

\section{Fiber percentage and morphometry of muscle fiber by ATPase staining}

The percentages of fiber types differentiated by the ATPase staining method were similar among treatments $(p>0.05)$. The percentages of slow fibers ranged between $9.19 \%$ and $12.34 \%$, and intermediate and fast fibers fluctuated from $49.28 \%$ to $55.62 \%$ and from $33.65 \%$ to $41.52 \%$, 
Table 4. Fibers ratio and cross-sectional areas of oxidative and glycolytic muscle fibers in the Longissimus thoracis muscle stained with the NADHTR technique

\begin{tabular}{|c|c|c|c|c|c|c|}
\hline \multirow{2}{*}{ Items } & \multicolumn{4}{|c|}{ Treatments ${ }^{1)}$} & \multirow{2}{*}{ SEM } & \multirow{2}{*}{$p$-value } \\
\hline & Control & FA300 & FA600 & $\mathrm{ZH}$ & & \\
\hline \multicolumn{7}{|c|}{ Fiber type ratios (\%) } \\
\hline Oxidative & 43.41 & 41.33 & 40.95 & 42.08 & 2.84 & 0.932 \\
\hline Glycolytic & 56.58 & 58.66 & 59.04 & 57.91 & 2.84 & 0.932 \\
\hline \multicolumn{7}{|l|}{$\operatorname{CSA}\left(\mu \mathrm{m}^{2}\right)$} \\
\hline Oxidative & $1,077.3^{\mathrm{a}}$ & $2,081.1^{b}$ & $1,836.2^{b}$ & $2,073.8^{b}$ & 157.7 & 0.003 \\
\hline Glycolytic & $1,619.2$ & $2,255.1$ & $1,738.5$ & $2,229.9$ & 267.7 & 0.274 \\
\hline
\end{tabular}

${ }^{11}$ Basal diet without additive (Control); basal diet plus $300 \mathrm{mg}$ of FAd $\mathrm{d}^{-1}$ (FA300); basal diet plus $600 \mathrm{mg}$ of FAd $^{-1}$ (FA600); basal diet plus zilpaterol hydrochloride at $6 \mathrm{mg} \mathrm{d}^{-1}(\mathrm{ZH})$. $\mathrm{n}=4$.

${ }^{a, b}$ Means with different superscripts in same row, indicate significant differences $(p<0.05)$.

FA, ferulic acid; ZH, zilpaterol hydrochloride; CSA, cross sectional area.

respectively (Table 5). The CSAs of the slow and intermediate fibers were not affected by the treatments $(p>0.05)$. The CSA of fast fibers was higher in the $\mathrm{ZH}$ treatment than in the other treatments $(p<0.05)$.

\section{Fiber density}

The treatments did not affect the fiber density $(p>0.05)$. However, FA300 and ZH had the lowest density values, which is in accordance with the higher CSA values, although this was not significant (Table 5).

\section{Gene expression on Longissimus thoracis muscle}

The mRNA abundance of $\beta_{2}$-AR, MHC-I, MHC-IIX, and IGF-I are shown in Figs 2, 3, 4, and 5. There was an effect of $\mathrm{ZH}$ on the mRNA concentrations of $\beta_{2}-\mathrm{AR}(p<0.05)$, and $\mathrm{ZH}$ treatment increased the $\beta_{2}$-AR expression three-fold for the FA doses and control groups $(p<0.05)$. The mRNA concentrations for $\beta_{2}$-AR in the FA300, FA600, and control groups were similar $(p>0.05)$. The FA300, FA600, and ZH treatments increased mRNA abundance of MHC-I compared to the non-supplemented animals $(p<0.05)$, with the mRNA values of experimental treatments

Table 5. Fibers ratio, cross sectional areas and density of slow, intermediate and fast muscle fibers in the Longissimus thoracis muscle stained with the ATPase technique

\begin{tabular}{|c|c|c|c|c|c|c|}
\hline \multirow{2}{*}{ Items } & \multicolumn{4}{|c|}{ Treatments $^{1)}$} & \multirow{2}{*}{ SEM } & \multirow{2}{*}{$p$-value } \\
\hline & Control & FA300 & FA600 & $\mathrm{ZH}$ & & \\
\hline \multicolumn{7}{|l|}{ Fiber type ratios (\%) } \\
\hline Intermediate & 36.53 & 41.52 & 33.65 & 37.84 & 7.66 & 0.906 \\
\hline Fast & 51.11 & 49.28 & 55.62 & 49.91 & 6.96 & 0.915 \\
\hline Intermediate & $1,477.0$ & $1,526.0$ & $1,512.5$ & $2,377.8$ & 332.7 & 0.223 \\
\hline Fast & $1,760.8^{\mathrm{a}}$ & $1,748.8^{\mathrm{a}}$ & $1,350.5^{\mathrm{a}}$ & $2,362.1^{b}$ & 255.9 & 0.049 \\
\hline Fiber density (fibers $/ 50,000 \mu \mathrm{m}^{2}$ ) & 23.14 & 17.77 & 26.02 & 20.15 & 2.67 & 0.207 \\
\hline
\end{tabular}

1)Basal diet without additive (Control); basal diet plus $300 \mathrm{mg}$ of FAd $^{-1}$ (FA300); basal diet plus $600 \mathrm{mg}$ of FA d$^{-1}$ (FA600); basal diet plus zilpaterol hydrochloride at $6 \mathrm{mg} \mathrm{d}^{-1}(\mathrm{ZH})$. $\mathrm{n}=4$.

$a, b$ Means with different superscripts in same row, indicate significant differences $(p<0.05)$.

FA, ferulic acid; ZH, zilpaterol hydrochloride; CSA, cross sectional area. 


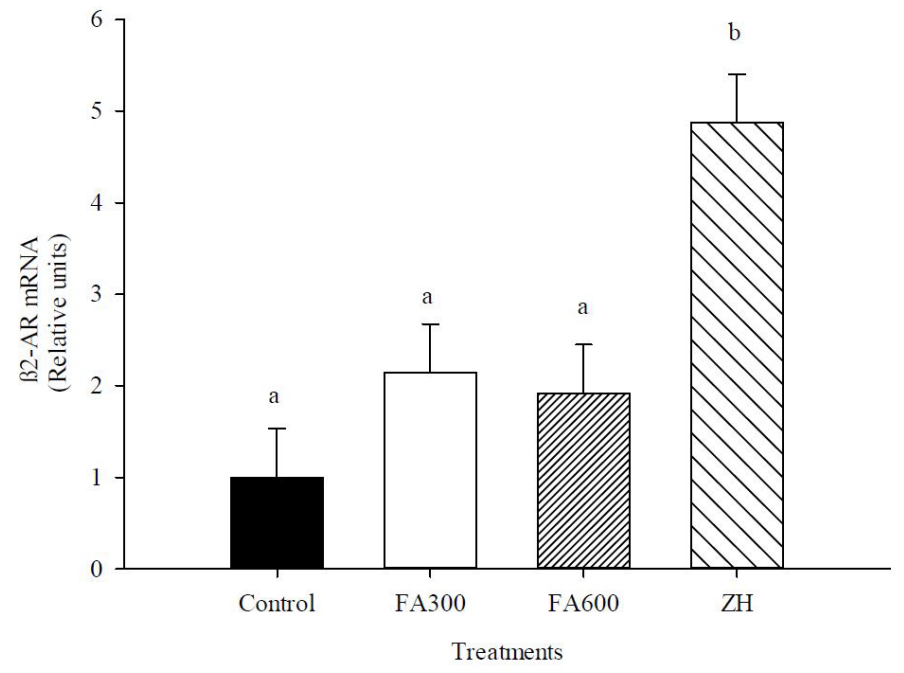

Fig. 2. Relative gene expression of $\beta 2$-adrenergic receptor ( $\beta 2$-AR) in Longissimus thoracis muscle of hairbreed lambs supplemented with ferulic acid or zilpaterol hydrochloride. Treatments, Basal diet without additive (Control); basal diet plus $300 \mathrm{mg}^{-1} \mathrm{FA} \mathrm{d}^{-1}$ (FA300); basal diet plus $600 \mathrm{mg}$ of FA d-1 (FA600); basal diet plus zilpaterol hydrochloride at $6 \mathrm{mg} \mathrm{d}^{-1}(\mathrm{ZH})$. Values are expressed as the mean $\pm \mathrm{SEM}$. ${ }^{\mathrm{a}, \mathrm{b}}$ Bars with different letters indicate significant differences at $p<0.05$. FA, ferulic acid; $\mathrm{ZH}$, zilpaterol hydrochloride.

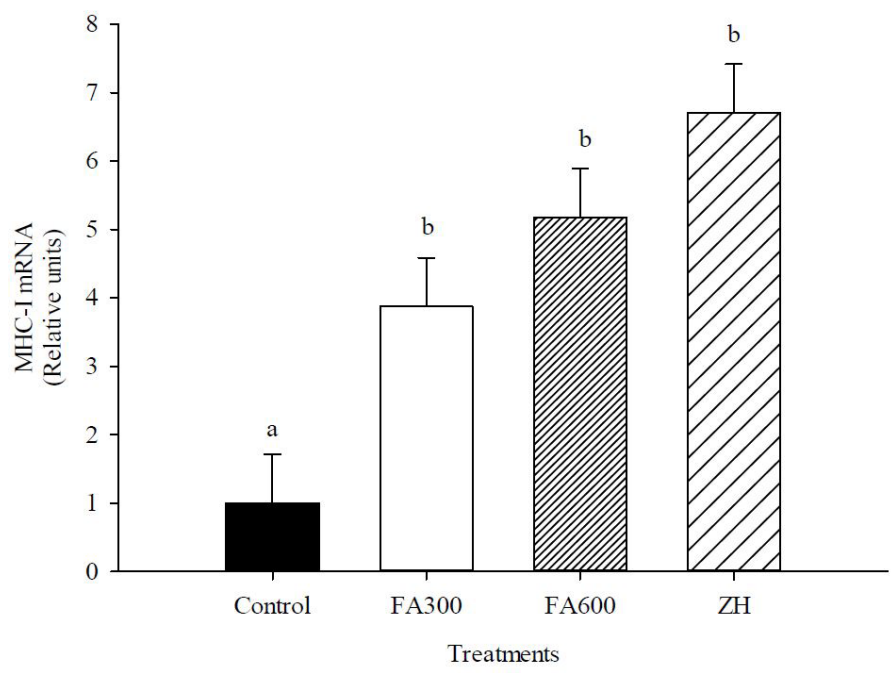

Fig. 3. Relative gene expression of myosin heavy chain-I (MHC-I) in Longissimus thoracis muscle of hairbreed lambs supplemented with ferulic acid or zilpaterol hydrochloride. Treatments, Basal diet without additive (Control); basal diet plus $300 \mathrm{mg}$ of FA d ${ }^{-1}$ (FA300); basal diet plus $600 \mathrm{mg}$ of FA d ${ }^{-1}$ (FA600); basal diet plus zilpaterol hydrochloride at $6 \mathrm{mg} \mathrm{d}^{-1}(\mathrm{ZH})$. Values are expressed as the mean $\pm \mathrm{SEM}$. ${ }^{\mathrm{a}, \mathrm{b}}$ Bars with different letters indicate significant differences at $p<0.05$. MHC, myosin heavy chain; FA, ferulic acid; ZH, zilpaterol hydrochloride.

fluctuating between 3 and 6.7 relative units. MHC-IIX gene expression changed only in the $\mathrm{ZH}$ treatment, and the synthetic molecule increased the mRNA abundance up to 3.7 relative units in the FA300, FA600, and control groups $(p<0.05)$. The mRNA levels of IGF-I were not altered by the experimental treatments, and the values oscillated between 1 and 2.04 relative units $(p>0.05)$. 


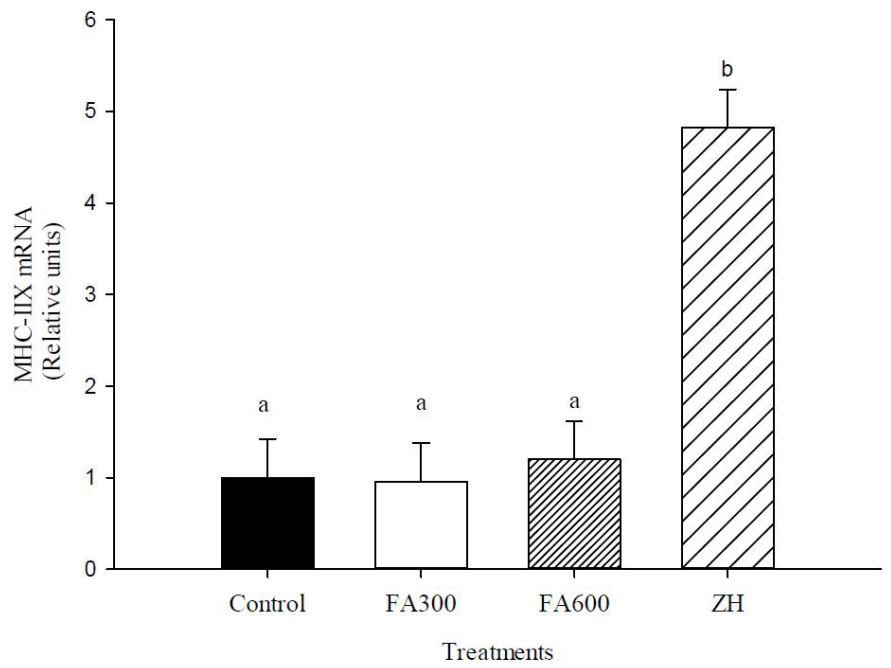

Fig. 4. Relative gene expression of myosin heavy chain-II (MHC-II) in Longissimus thoracis muscle of hairbreed lambs supplemented with ferulic acid or zilpaterol hydrochloride. Treatments, Basal diet without additive (Control); basal diet plus $300 \mathrm{mg}^{-1} \mathrm{FA} \mathrm{d}^{-1}$ (FA300); basal diet plus $600 \mathrm{mg}$ of FA d-1 (FA600); basal diet plus zilpaterol hydrochloride at $6 \mathrm{mg} \mathrm{d}^{-1}(\mathrm{ZH})$. Values are expressed as the mean $\pm \mathrm{SEM}$. ${ }^{\mathrm{a}, \mathrm{b}} \mathrm{Bars}$ with different letters indicate significant differences at $p<0.05$. MHC, myosin heavy chain; FA, ferulic acid; $\mathrm{ZH}$, zilpaterol hydrochloride.

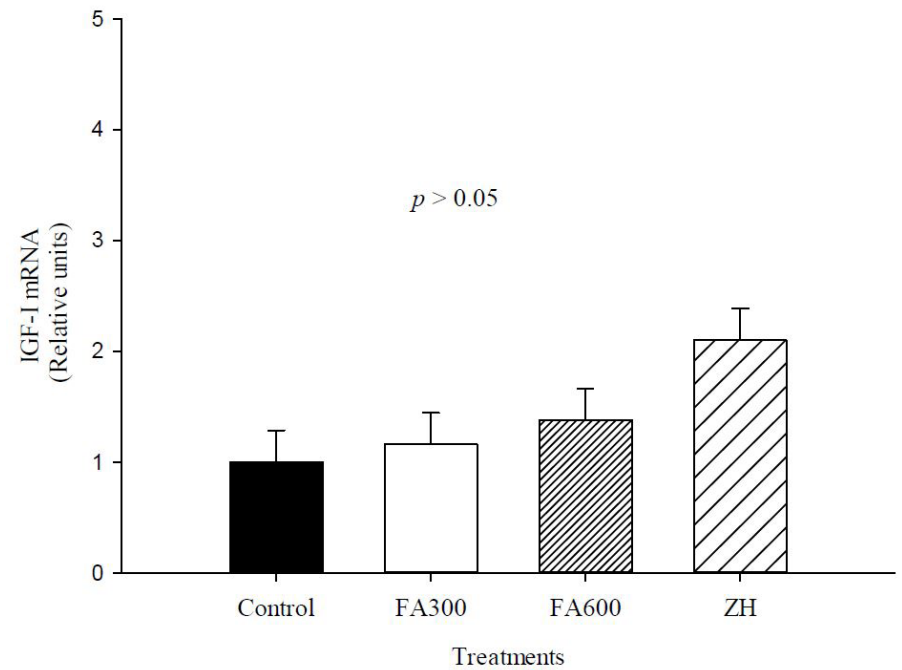

Fig. 5. Relative gene expression of insulin growth factor-I (IGF-I) in Longissimus thoracis muscle of hairbreed lambs supplemented with ferulic acid or zilpaterol hydrochloride. Treatments, Basal diet without additive (Control); basal diet plus $300 \mathrm{mg}^{-1} \mathrm{FA} \mathrm{d}^{-1}$ (FA300); basal diet plus $600 \mathrm{mg}^{-} \mathrm{FA} \mathrm{d}^{-1}$ (FA600); basal diet plus zilpaterol hydrochloride at $6 \mathrm{mg} \mathrm{d}^{-1}(\mathrm{ZH})$. Values are expressed as the mean $\pm \mathrm{SEM}$. FA, ferulic acid; ZH, zilpaterol hydrochloride.

\section{DISCUSSION}

\section{Growth performance and carcass characteristics}

The feedlot performance of the FA and $\mathrm{ZH}$ treatments in the present study was similar with other studies that used $\mathrm{ZH}$ in finishing lambs, with increase in $\mathrm{ADG}$ and improved feed conversion 
$[22,23]$. These modifications on growth performance are well documented as a repartitioning effect caused by $\beta$-AA and are the most important production parameters [24]. However, other studies in lambs have reported contrary results. Dávila-Ramírez et al. [25] and Macías-Cruz et al. [26] evaluated feedlot performance in hair lambs with $10 \mathrm{mg} \mathrm{d}^{-1}$ of $\mathrm{ZH}$ and did not observe changes in ADG and feed efficiency, due to environmental factors as heat stress, that reduce voluntary feed and metabolizable energy intake [27].

Studies related to the effects of FA supplementation on productive species are limited and inconsistent. Results of the present study agree with a previous study of finishing heifers supplemented with FA (2,250 or 4,500 $\left.\mathrm{mg} \mathrm{FA} \mathrm{d}^{-1}\right)$ where an increase of ADG and feed conversion was observed compared to non-supplemented animals [6]. Another study on ewe lambs reported an increase on wholesale cut yields when they were supplemented for 40 days with $250 \mathrm{mg} \mathrm{kg}^{-1}$ of FA under extreme heat stress [7]. In contrast, a previous study observed no effects on feedlot performance when ewe lambs were supplemented with $300 \mathrm{mg} \mathrm{d}^{-1} \mathrm{FA}$ for $34 \mathrm{~d}$ under heat stress conditions [28].

The mode of action of FA has not yet been completely elucidated and a study in lactating cows supplemented with FA associated a hormonal mechanism as result of an increase of serum somatotropin [29]. By other hand, in a study on finishing pigs supplemented with FA, hypothesized a $\beta$-AA mechanism, due to improvements in final body weight, feed conversion, carcass yields and overexpression of $\beta$-AR, IGF-I, and MHC-I, similar to pigs with ractopamine hydrochloride treatment [30], however, is necessary more studies focused on myogenic regulatory factors (MRFs) and endogenous proteolytic systems to confirm an anabolic mechanism of FA. In addition, a modulating effect of the rumen microbiota has been suggested as other mode of action of FA because there is evidence that isolated extracts from plants directly affect the rumen or intestinal microbial ecosystem, generating beneficial changes in volatile fatty acids, which are the first energy source in ruminants $[1,31,32]$.

Concerning the carcass parameters, the $\mathrm{pH}$ parameters were similar for all treatments and within normal values for the fresh meat of lambs [33]. Only the ZH treatment showed a significant increase in LT muscle area, which has been well documented in other reports and explained by protein synthesis activation and repartitioning effect in LT muscle [8,34].

Despite the important benefits of FA in the feedlot, the carcasses of these animals were similar to those of the control group. Similar results were reported by Macías-Cruz et al. [35] except in the LT area; therefore, $\mathrm{ZH}$ supplementation in hair lambs does not result in changes in carcass variables. In contrast, in pigs supplemented with FA, fat thickness was significantly reduced by supplementation with $50 \mathrm{mg} \mathrm{FA} \mathrm{kg}{ }^{-1}$ of feed, suggesting a lipolytic effect [5]. An explanation of the contrasting results in the feedlot and carcass with FA in the present study could be that compensatory growth from the high-energy diet, the age of the lambs (4 months), or the different origin of the animals caused these changes [36]. In the present study, it was not possible to measure the weight of organs and non-carcass components. The literature indicates that $\beta$-AA has little effect on organs and noncarcass components such as the liver, intestine, and skin, or the redirection of nutrients from the organs for muscle development; in this sense, is necessary further studies because FA metabolism could be distinct in gastrointestinal tract in ruminants and there is also the possibility that orally ingested FA can be degraded or transformed in the rumen, resulting in a diminished FA effect in the skeletal muscle [37].

Therefore, precise experiments should be performed on the kinetics of ruminal microbiota, volatile fatty acid proportions, metabolic routes, and pharmacodynamics to establish the action mechanism and effective FA doses. 


\section{Morphometry of muscle fibers}

Similar to the present study, FA caused a hypertrophy effect in pigs supplemented with $50 \mathrm{mg} \mathrm{d}^{-1}$, where the CSA increased fast twitch fibers owing to the upregulation of MHC-IIX and IGF-1 genes [30]. Furthermore, in male rats (12 weeks old) supplemented with $0.5 \%$ apple polyphenols for 8 weeks, an increased CSA in oxidative fibers was observed due to the upregulation of MHC type I [38]. A recent study in 21-day-old piglets demonstrated that FA could promote muscle fiber type conversion from fast-twitch to slow-twitch via the Sirt1/AMPK/PGC-1 $\alpha$ signaling pathway, moreover a decrease of lactate dehydrogenase (LDH) activity, that is positively associated with glycolytic fibers confirming that FA could promote the transformation of muscle fiber type from fast-twitch to slow-twitch. [39].

$\beta-\mathrm{AA}$ is used during the finishing phases of productive species and these compounds generate increases in muscle mass and carcass yields caused by muscle hypertrophy [8]. The treatments in the present study presented similar behavior as those lambs supplemented with $\beta$-AA cimaterol, which caused an increase in CSA by 50\% compared to the non-supplemented group and there were no changes in the proportion of oxidative and glycolytic fibers [40]. The same effect was presented in steers with $\mathrm{ZH}+$ anabolic implants that contained CSA of fibers type I and IIX in longissimus lumborum that were higher than that of the non-supplemented group [41]. One explanation for this can be attributed to $\beta_{2}-\mathrm{AR}$ activation of the stem cells generating overexpression of $\mathrm{MHC}$ protein isoforms and greater muscle development [8]. The present study results did not show differences between fiber ratios; however, it can note that $\mathrm{FA}$ and $\mathrm{ZH}$ treatments have ratios of glycolytic slightly above, that could suggest a light muscle fiber transition as occurs with $\beta$-AA molecules $[11,41]$, and repartitioning the energy from nutrients to glycolytic fibers, which could be reflected in more wholesale cuts yields [8].

\section{Gene expression in Longissimus thoracis muscle}

To the best of our knowledge, this is the first study to evaluate the effect of FA inclusion on gene expression in hair lambs. Previous studies tested FA in bovine satellite cells (in vitro) and the muscle of pigs (in vivo) and found high levels of mRNA relative abundance for $\beta_{2}-\mathrm{AR}$, similar to $\beta-\mathrm{AA}$ $[30,42]$. These differences in our study might be because FA does not bind to $\beta_{2}-\mathrm{AR}$ and there might be other receptors or other mechanisms that recognize FA and promote muscle deposition. A recent study indicates that FA has mitochondrial and enzymatic pathways that promote fiber type conversion from fast-twitch to slow-twitch and myogenic regulators targeting hypertrophy in oxidative fibers [39]. Therefore, further research is required to confirm the initial action mechanism of FA to promote growth in lambs.

$\beta$-AAs are recognized by membrane receptors in skeletal muscle $\left(\beta_{1}-\mathrm{AR}\right.$ and $\left.\beta_{2}-\mathrm{AR}\right)$ and increase cell transcription and translation directed to muscle protein synthesis, lipolysis, and the rate reduction of protein degradation [8]. The literature indicates that the $\beta_{2}-\mathrm{AR}$ subtype showed an increase in mRNA levels more than $\beta_{1}-\mathrm{AR}$ in steers after $\mathrm{ZH}$ treatment, which confirms our results with $\mathrm{ZH}$ in hair lambs $[43,44]$.

The results of mRNA abundance of MHC-I with FA and $\mathrm{ZH}$ treatments are in accordance with the increase of CSA for slow or oxidative fibers. In other studies whit FA extracted from gamma oryzanol, was increased muscular straightness and induced larger increases in exercise capacity and antifatigue, which were related to the characteristics and properties of slow fibers and oxidative metabolism, including fatigue resistance $[45,46]$. Similarly, the capillarity of muscle fibers directly influences the morphology, development, and maintenance of muscle fibers. Capillaries surround the muscle fiber, and the number of capillaries is higher in type I fibers (oxidative) than in type II fibers (glycolytic); therefore, the supply of nutrients and energy can be directed to anabolism [47,48] 
and this mechanism helps increase MHC-I levels with FA. MHC-IIX expression levels were not modified in hair lambs with FA300 or FA600 treatments, coinciding with the null differences found in the CSA of fast and glycolytic fibers. Therefore, the growth promoter of FA is limited only by MHC-I expression, which is supported by studies showing that FA improved muscle strength in steers and increased the relative abundance of mRNA for MHC in satellite cells [25,49]. Other studies have evaluated the gene expression of antioxidant enzymes such as glutathione peroxidase and catalase or immune system as pro-inflammatory cytokines and showed that FA helped improve the health status of animals, which could be another mode of action for growth promotion $[50,51,52]$.

On the other hand, the mode of action of FA, also could be hypothesized like a mimic of $\beta-A A$, since recently a study with the phytochemical higenamine from herbal extracts evidenced an activation of $\beta_{1}-A R, \beta_{2}-A R$ and $G$ proteins in cultured myocardial cells [53]. However, more studies are required to confirm this possible mechanism of action.

Respect to effect of $\mathrm{ZH}$, a study with cimaterol hydrochloride in hair lambs showed muscle hypertrophy in slow fibers, in comparison the fiber size increased the MHC-I overexpression compared to the non-supplemented group [54]. The relative abundance of MHC-IIX in the ZH treatment in the present study was consistent with other studies in bovines with $\mathrm{ZH}$ treatment, which altered the levels of MHC-IIX in LT and Semimembranosus muscles [19,55]. Our results with $\mathrm{ZH}$ corresponded with the usual mode of action of $\beta$-AA in bovines, provoking a transition from oxidative fibers to predominantly glycolytic fibers, which was influenced by an alteration in the MHC-IIA and MHC-IIX isoforms with a major effect or improvements on feed efficiency, ADG, carcass dressing, and primary cuts [24]. This effect is consistent with the increase in the glycolytic fiber size with $\mathrm{ZH}$, confirming the action mechanism of $\beta$-AA compounds reported in ruminants, which promotes muscle hypertrophy.

The growth promoter action for IGF-I activation is via the proliferation of satellite cells and muscle mass growth, and studies of mRNA abundance of this gene have shown such an effect $[56,57]$. Our results with FA did not present significant values and contrast with a study on pigs supplemented with FA, where mRNA abundance was higher than the $\beta$-AA treatment [30].

In ruminants, several studies have evaluated this hormonal indicator, without changes in IGF-I with $\beta$-AA treatment. Satellite cells of bovines were probed with $\mathrm{ZH}$, and the relative abundance of IGF-I mRNA at $192 \mathrm{~h}$ was zero [42]. In addition, ewe lambs supplemented with clenbuterol hydrochloride had incremented muscle weight but not plasma IGF-I concentration [58]. Dikeman et al. [59] indicated that the administration of $\beta$-AA reduced IGF-I mRNA in skeletal muscle and circulating IGF-I because IGF-I is a stimulator of satellite cell proliferation with no apparent change in DNA content and limits the capacity to sustain muscle hypertrophy.

\section{CONCLUSION}

FA administration in hair lambs produced a muscle hypertrophy effect on productive and physiological variables; however, this was not reflected in the carcass characteristics. Future studies should be carried out to confirm whether an activation of $\beta$-AR occurs and to be able to associate it with the increase in muscle deposition after supplementation with FA in hair lambs, or to investigate intracellular pathways involved in this response. For $\mathrm{ZH}$, the action mode as a growth promoter in lambs was confirmed, which was recognized in $\beta 2-\mathrm{AR}$ and caused an upregulation of $\mathrm{MHC}$ isoforms and an increase in the size of both fiber types. In conclusion, FA can be one of the candidate agents to improve the muscle growth in intensive feedlot lambs; however, further studies are required to elucidate the effective doses that increase the economic benefit of wholesale cut yields. 


\section{REFERENCES}

1. García-González R, López S, Fernández M, Bodas R, González JS. Screening the activity of plants and spices for decreasing ruminal methane production in vitro. Anim Feed Sci Technol. 2008;147:36-52. https://doi.org/10.1016/j.anifeedsci.2007.09.008

2. Kumar A, Kanwar SS. Synthesis of ethyl ferulate in organic medium using celite-immobilized lipase. Bioresour Technol. 2011;102:2162-7. https://doi.org/10.1016/j.biortech.2010.10.027

3. Zhao Z, Moghadasian MH. Chemistry, natural sources, dietary intake and pharmacokinetic properties of ferulic acid: a review. Food Chem. 2008;109:691-702. https://doi.org/10.1016/ j.foodchem.2008.02.039

4. González-Ríos H, Dávila-Ramírez JL, Peña-Ramos EA, Valenzuela-Melendres M, Zamorano-García L, Islava-Lagarda TY, et al. Dietary supplementation of ferulic acid to steers under commercial feedlot feeding conditions improves meat quality and shelf life. Anim Feed Sci Technol. 2016;222:111-21. https://doi.org/10.1016/j.anifeedsci.2016.10.011

5. Herrera RH, Castillo MLA, Torres AJA. Methods to accelerate muscle development, decrease fat deposits, and enhance feeding efficiency in pigs. United States Patent US20110046224A1. 2009.

6. Peña-Torres EF, Dávila-Ramírez JL, Peña-Ramos EA, Valenzuela-Melendres M, PinelliSaavedra A, Avendaño-Reyes L, et al. Effects of dietary ferulic acid on growth performance, carcass traits and meat quality of heifers. J Sci Food Agric. 2021;101:548-54. https://doi. org/10.1002/jsfa.10666

7. Valadez-García KM, Avendaño-Reyes L, Díaz-Molina R, Mellado M, Meza-Herrera CA, Correa-Calderón A, et al. Free ferulic acid supplementation of heat-stressed hair ewe lambs: oxidative status, feedlot performance, carcass traits and meat quality. Meat Sci. 2021;173:108395. https://doi.org/10.1016/j.meatsci.2020.108395

8. Beermann DH. Beta-adrenergic receptor agonist modulation of skeletal muscle growth. J Anim Sci. 2002;80:E18-23. https://doi.org/10.2527/animalsci2002.0021881200800ES10004x

9. Mersmann HJ. Overview of the effects of $\beta$-adrenergic receptor agonists on animal growth including mechanisms of action. J Anim Sci. 1998;76:160-72. https://doi. org/10.2527/1998.761160x

10. Miller EK, Chung KY, Hutcheson JP, Yates DA, Smith SB, Johnson BJ. Zilpaterol hydrochloride alters abundance of $\beta$-adrenergic receptors in bovine muscle cells but has little effect on de novo fatty acid biosynthesis in bovine subcutaneous adipose tissue explants.J Anim Sci. 2012;90:1317-27. https://doi.org/10.2527/jas.2011-4589

11. Strydom PE, Frylinck L, Montgomery JL, Smith MF. The comparison of three $\beta$-agonists for growth performance, carcass characteristics and meat quality of feedlot cattle. Meat Sci. 2009;81:557-64. https://doi.org/10.1016/j.meatsci.2008.10.011

12. Avendaño-Reyes L, Torres-Rodríguez V, Meraz-Murillo FJ, Pérez-Linares C, FigueroaSaavedra F, Robinson PH. Effects of two $\beta$-adrenergic agonists on finishing performance, carcass characteristics, and meat quality of feedlot steers. J Anim Sci. 2006;84:3259-65. https:// doi.org/10.2527/jas.2006-173

13. Hope-Jones M, Strydom PE, Frylinck L, Webb EC. The efficiency of electrical stimulation to counteract the negative effects of $\beta$-agonists on meat tenderness of feedlot cattle. Meat Sci. 2010;86:699-705. https://doi.org/10.1016/j.meatsci.2010.06.008

14. Hahn GL. Dynamic responses of cattle to thermal heat loads. J Anim Sci. 1999;77:10-20. https://doi.org/10.2527/1997.77suppl_210x

15. Nachlas MM, Walker DG, Seligman AM. A histochemical method for the demonstration of 
diphosphopyridine nucleotide diaphorase.J Biophys Biochem Cytol. 1958;4:29-38. https://doi. org/10.1083/jcb.4.1.29

16. Guth L, Samaha FJ. Procedure for the histochemical demonstration of actomyosin ATPase. Exp Neurol. 1970;28:365-7. https://doi.org/10.1016/0014-4886(70)90244-X

17. López-García K, Mariscal-Tovar S, Serrano-Meneses MA, Castelán F, Martínez-Gómez M, Jiménez-Estrada I. Fiber type composition of pubococcygeus and bulbospongiosus striated muscles is modified by multiparity in the rabbit. Neurourol Urodyn. 2017;36:1456-63. https:// doi.org/10.1002/nau.23143

18. Valenzuela-Grijalva N, Jiménez-Estrada I, Mariscal-Tovar S, López-García K, Pinelli-Saavedra A, Peña-Ramos EA, et al. Effects of ferulic acid supplementation on growth performance, carcass traits and histochemical characteristics of muscle fibers in finishing pigs. Animals. 2021;11:2455. https://doi.org/10.3390/ani11082455

19. Baxa TJ, Hutcheson JP, Miller MF, Brooks JC, Nichols WT, Streeter MN, et al. Additive effects of a steroidal implant and zilpaterol hydrochloride on feedlot performance, carcass characteristics, and skeletal muscle messenger ribonucleic acid abundance in finishing steers. J Anim Sci. 2010;88:330-7. https://doi.org/10.2527/jas.2009-1797

20. Tsiplakou E, Flemetakis E, Kouri ED, Sotirakoglou K, Zervas G. The effect of long term under- and over-feeding on the expression of genes related to glucose metabolism in mammary tissue of sheep. J Dairy Res. 2015;82:228-35. https://doi.org/10.1017/S0022029915000072

21. Livak KJ, Schmittgen TD. Analysis of relative gene expression data using real-time quantitative PCR and the 2- $\Delta \Delta \mathrm{CT}$ method. Methods. 2001;25:402-8. https://doi.org/10.1006/ meth.2001.1262

22. Avendaño-Reyes L, Macías-Cruz U, Álvarez-Valenzuela FD, Águila-Tepato E, TorrenteraOlivera NG, Soto-Navarro SA. Effects of zilpaterol hydrochloride on growth performance, carcass characteristics, and wholesale cut yield of hair-breed ewe lambs consuming feedlot diets under moderate environmental conditions. J Anim Sci. 2011;89:4188-94. https://doi. org/10.2527/jas.2011-3904

23. Estrada-Angulo A, Barreras-Serrano A, Contreras G, Obregon JF, Robles-Estrada JC, Plascencia A, et al. Influence of level of zilpaterol chlorhydrate supplementation on growth performance and carcass characteristics of feedlot lambs. Small Rumin Res. 2008;80:107-10. https://doi.org/10.1016/j.smallrumres.2008.09.006

24. Johnson BJ, Smith SB, Chung KY. Historical overview of the effect of $\beta$-adrenergic agonists on beef cattle production. Asian-Australas J Anim Sci. 2014;27:757-66. https://doi.org/10.5713/ ajas.2012.12524

25. Dávila-Ramírez JL, Macías-Cruz U, Torrentera-Olivera NG, González-Ríos H, Soto-Navarro SA, Rojo-Rubio R, et al. Effects of zilpaterol hydrochloride and soybean oil supplementation on feedlot performance and carcass characteristics of hair-breed ram lambs under heat stress conditions.J Anim Sci. 2014;92:1184-92. https://doi.org/10.2527/jas.2012-6214

26. Macías-Cruz U, Avendaño-Reyes L, Álvarez-Valenzuela FD, Torrentera-Olivera NG, MezaHerrera C, Mellado-Bosque M, et al. Crecimiento y características de canal en corderas tratadas con clorhidrato de zilpaterol durante primavera y verano. Rev Mex Cienc Pecu. 2013;4:1-12.

27. Bernabucci U, Lacetera N, Baumgard LH, Rhoads RP, Ronchi B, Nardone A. Metabolic and hormonal acclimation to heat stress in domesticated ruminants. Animal. 2010;4:1167-83. https://doi.org/10.1017/S175173111000090X

28. Macías-Cruz U, Perard S, Vicente R, Álvarez FD, Torrentera-Olivera NG, González-Ríos $\mathrm{H}$, et al. Effects of free ferulic acid on productive performance, blood metabolites, and carcass characteristics of feedlot finishing ewe lambs. J Anim Sci. 2014;92:5762-8. https://doi. 
org/10.2527/jas.2014-8208

29. Gorewit RC. Pituitary and thyroid hormone responses of heifers after ferulic acid administration. J Dairy Sci. 1983;66:624-9. https://doi.org/10.3168/jds.S0022-0302(83)81834-7

30. Valenzuela N. Ácido ferúlico como promotor del crecimiento en cerdos: mecanismo y efectos sobre la deposición de tejido muscular [Ph.D. dissertation]. Sonora, Mexico: Centro de Investigación en Alimentación y Desarrollo; 2017.

31. Busquet M, Calsamiglia S, Ferret A, Kamel C. Plant extracts affect in vitro rumen microbial fermentation.J Dairy Sci. 2006;89:761-71. https://doi.org/10.3168/jds.S0022-0302(06)72137-3

32. Valenzuela-Grijalva NV, Pinelli-Saavedra A, Muhlia-Almazan A, Domínguez-Díaz D, González-Ríos H. Dietary inclusion effects of phytochemicals as growth promoters in animal production.J Anim Sci Technol. 2017;59:8. https://doi.org/10.1186/s40781-017-0133-9

33. Mach N, Bach A, Velarde A, Devant M. Association between animal, transportation, slaughterhouse practices, and meat $\mathrm{pH}$ in beef. Meat Sci. 2008;78:232-8. https://doi. org/10.1016/j.meatsci.2007.06.021

34. Vahedi V, Towhidi A, Zare Shahneh A, Sadeghi M, Zamani F, Dunshea FR. Effects of $\beta$-agonist zilpaterol hydrochloride feeding and supplementation period on growth and carcass characteristics of Lori-Bakhtiari lambs. Small Rumin Res. 2014;119:65-71. https://doi. org/10.1016/j.smallrumres.2014.01.005

35. Macías-Cruz U, López-Baca MA, Vicente R, Mejía A, Álvarez FD, Correa-Calderón A, et al. Effects of seasonal ambient heat stress (spring vs. summer) on physiological and metabolic variables in hair sheep located in an arid region. Int J Biometeorol. 2016;60:1279-86. https:// doi.org/10.1007/s00484-015-1123-6

36. te Pas MFW, Everts ME, Haagsman HP. Muscle development of livestock animals: physiology, genetics and meat quality. Wallingford, UK: CABI; 2004. p. 432.

37. Peña-Torres EF, González-Ríos H, Avendaño-Reyes L, Valenzuela-Grijalva NV, PinelliSaavedra A, Muhlia-Almazán A, et al. Hydroxycinnamic acids in animal production: pharmacokinetics, pharmacodynamics and growth promoting effects. Review. Rev Mex Cienc Pecu. 2019;10:391-415. https://doi.org/10.22319/rmcp.v10i2.4526

38. Mizunoya W, Okamoto S, Miyahara H, Akahoshi M, Suzuki T, Do MQ, et al. Fast-to-slow shift of muscle fiber-type composition by dietary apple polyphenols in rats: impact of the lowdose supplementation. Anim Sci J.2017;88:489-99. https://doi.org/10.1111/asj.12655

39. Wang Y, Chen X, Huang Z, Chen D, Yu B, Chen H, et al. Effects of dietary ferulic acid supplementation on growth performance and skeletal muscle fiber type conversion in weaned piglets.J Sci Food Agric. 2021;101:5116-23. https://doi.org/10.1002/jsfa.11157

40. Kim YS, Lee YB, Dalrymple RH. Effect of the repartitioning agent cimaterol on growth, carcass and skeletal muscle characteristics in lambs. J Anim Sci. 1987;65:1392-9. https://doi. org/10.2527/jas1987.6551392x

41. Kellermeier JD, Tittor AW, Brooks JC, Galyean ML, Yates DA, Hutcheson JP, et al. Effects of zilpaterol hydrochloride with or without an estrogen-trenbolone acetate terminal implant on carcass traits, retail cutout, tenderness, and muscle fiber diameter in finishing steers.J Anim Sci. 2009;87:3702-11. https://doi.org/10.2527/jas.2009-1823

42. Platt JP, Anderson MJ, Johnson BJ. The effect of ferulic acid on myogenic regulators of growth in bovine satellite cells. Paper presented at: Texas Tech University Undergraduate Research Conference; 2012; Lubbock, TX.

43. Montgomery JL, Krehbiel CR, Cranston JJ, Yates DA, Hutcheson JP, Nichols WT, et al. Dietary zilpaterol hydrochloride. I. Feedlot performance and carcass traits of steers and heifers. J Anim Sci. 2009;87:1374-83. https://doi.org/10.2527/jas.2008-1162 
44. Reeds PJ, Mersmann HJ. Protein and energy requirements of animals treated with $\beta$-adrenergic agonists: a discussion.J Anim Sci. 1991;69:1532-50. https://doi.org/10.2527/1991.6941532x

45. Eslami S, Esa NM, Marandi SM, Ghasemi G, Eslami S. Effects of gamma oryzanol supplementation on anthropometric measurements \& muscular strength in healthy males following chronic resistance training. Indian J Med Res. 2014;139:857-63.

46. Kim KM, Yu KW, Kang DH, Koh JH, Hong BS, Suh HJ. Anti-stress and anti-fatigue effects of fermented rice bran. Biosci Biotechnol Biochem. 2001;65:2294-6. https://doi.org/10.1271/ bbb.65.2294

47. Gonzalez JM, Johnson SE, Stelzleni AM, Thrift TA, Savell JD, Warnock TM, et al. Effect of ractopamine- $\mathrm{HCl}$ supplementation for 28 days on carcass characteristics, muscle fiber morphometrics, and whole muscle yields of six distinct muscles of the loin and round. Meat Sci. 2010;85:379-84. https://doi.org/10.1016/j.meatsci.2010.02.004

48. Karlström K, Essén-Gustavsson B, Lindholm A, Persson SGB. Capillary supply in relation to muscle metabolic profile and cardiocirculatory parameters. Equine Exerc Physiol. 1991;3:23944.

49. Gonzalez JM, Carter JN, Johnson DD, Ouellette SE, Johnson SE. Effect of ractopaminehydrochloride and trenbolone acetate on longissimus muscle fiber area, diameter, and satellite cell numbers in cull beef cows. J Anim Sci. 2007;85:1893-901. https://doi.org/10.2527/ jas.2006-624

50. Lee MT, Lin WC, Yu B, Lee TT. Antioxidant capacity of phytochemicals and their potential effects on oxidative status in animals: a review. Asian-Australas J Anim Sci. 2017;30:299-308. https://doi.org/10.5713/ajas.16.0438

51. Li YJ, Li LY, Li JL, Zhang L, Gao F, Zhou GH. Effects of dietary supplementation with ferulic acid or vitamin $\mathrm{E}$ individually or in combination on meat quality and antioxidant capacity of finishing pigs. Asian-Australas J Anim Sci. 2015;28:374-81. https://doi.org/10.5713/ajas.14.0432

52. Paraskeuas V, Fegeros K, Hunger C, Theodorou G, Mountzouris KC. Dietary inclusion level effects of a phytogenic characterised by menthol and anethole on broiler growth performance, biochemical parameters including total antioxidant capacity and gene expression of immunerelated biomarkers. Anim Prod Sci. 2016;57:33-41. https://doi.org/10.1071/AN15367

53. Chen Y, Guo B, Zhang H, Hu L, Wang J. Higenamine, a dual agonist for $\beta 1$ - and $\beta 2$ adrenergic receptors identified by screening a traditional Chinese medicine library. Planta Med. 2019;85:738-44. https://doi.org/10.1055/a-0942-4502

54. Beermann DH, Butler WR, Hogue DE, Fishell VK, Dalrymple RH, Ricks CA, et al. Cimaterol-induced muscle hypertrophy and altered endocrine status in lambs. J Anim Sci. 1987;65:1514-24. https://doi.org/10.2527/jas1987.6561514x

55. Rathmann RJ, Mehaffey JM, Baxa TJ, Nichols WT, Yates DA, Hutcheson JP, et al. Effects of duration of zilpaterol hydrochloride and days on the finishing diet on carcass cutability, composition, tenderness, and skeletal muscle gene expression in feedlot steers. J Anim Sci. 2009;87:3686-701. https://doi.org/10.2527/jas.2009-1818

56. Hayashi S, Aso H, Watanabe K, Nara H, Rose MT, Ohwada S, et al. Sequence of IGF-I, IGFII, and HGF expression in regenerating skeletal muscle. Histochem Cell Biol. 2000;122:42734. https://doi.org/10.1007/s00418-004-0704-y

57. Shavlakadze T, Winn N, Rosenthal N, Grounds MD. Reconciling data from transgenic mice that overexpress IGF-I specifically in skeletal muscle. Growth Horm IGF Res. 2005;15:4-18. https://doi.org/10.1016/j.ghir.2004.11.001

58. Young OA, Watkins S, Oldham JM, Bass JJ. The role of insulin-like growth factor I in clenbuterol-stimulated growth in growing lambs. J Anim Sci. 1995;73:3069-77. https://doi. 
org/10.2527/1995.73103069x

59. Anderson PT, Johnson B, Dikeman M. Growth of meat animals metabolic modifiers. In: Devine C, Dikeman M, editors. Encyclopedia of meat sciences. 2nd ed. Cambridge, MA: Academic Press; 2014. p. 62-9. 